\title{
INHIBITORS OF HYDROPEROXIDE METABOLISM ENHANCE ASCORBATE-INDUCED CYTOTOXICITY
}

\author{
Kristen E. Olney, Juan Du, Thomas J. van 't Erve, Jordan R. Witmer, Zita A. Sibenaller, \\ Brett A. Wagner, Garry R. Buettner, and Joseph J. Cullen \\ Departments of Radiation Oncology (KEO, JD, JRW, ZAS, BAW, GRB, JJC), Toxicology (TJvE) \\ and Surgery (JJC), University of lowa College of Medicine, lowa City, IA, the Holden \\ Comprehensive Cancer Center (GRB, JJC), and the Veterans Affairs Medical Center (JJC), lowa \\ City, IA
}

\begin{abstract}
Pharmacological ascorbate, via its oxidation, has been proposed as a pro-drug for the delivery of $\mathrm{H}_{2} \mathrm{O}_{2}$ to tumors. Pharmacological ascorbate decreases clonogenic survival of pancreatic cancer cells, which can be reversed by treatment with scavengers of $\mathrm{H}_{2} \mathrm{O}_{2}$. The goal of this study was to determine if inhibitors of intracellular hydroperoxide detoxification could enhance the cytotoxic effects of ascorbate. Human pancreatic cancer cells were treated with ascorbate alone or in combination with inhibitors of hydroperoxide removal including the glutathione disulfide reductase inhibitor 1,3 bis (2-chloroethyl)-1-nitrosurea (BCNU), siRNA targeted to glutathione disulfide reductase (siGR), and 2-deoxy-D-glucose (2DG), which inhibits glucose metabolism. Changes in the intracellular concentration of $\mathrm{H}_{2} \mathrm{O}_{2}$ were determined by analysis of the rate of aminotriazole-mediated inactivation of endogenous catalase activity. Pharmacological ascorbate increased intracellular $\mathrm{H}_{2} \mathrm{O}_{2}$ and depleted intracellular glutathione. When inhibitors of $\mathrm{H}_{2} \mathrm{O}_{2}$ metabolism were combined with pharmacological ascorbate the increase in intracellular $\mathrm{H}_{2} \mathrm{O}_{2}$ was amplified and cytotoxicity was enhanced. We conclude that inclusion of agents that inhibit cellular peroxide removal produced by pharmacological ascorbate leads to changes in the intracellular redox state resulting in enhanced cytotoxicity.
\end{abstract}

\section{Keywords}

hydrogen peroxide; glutathione disulfide reductase; catalase; oxidative stress; pancreatic cancer

\section{INTRODUCTION}

Pharmacological ascorbate is high-dose ascorbate (ascorbic acid, vitamin C) delivered intravenously to achieve plasma levels that are $100-1000$ times that of normal nutritional levels. These high levels are only possible with intravenously delivered ascorbate, not oral ascorbate [1, 2, 3]. These levels are in the range that can be cytotoxic to tumor cells [4]. Recent studies from our group have demonstrated that ascorbate induces cytotoxicity and oxidative stress in pancreatic cancer cells and this cytotoxicity appears to be greater in tumor Vs. normal cells [5]. Pharmacological ascorbate has been hypothesized to be a pro-drug for formation of hydrogen peroxide $\left(\mathrm{H}_{2} \mathrm{O}_{2}\right)$ [4]; ascorbate is oxidized to ascorbate radical by redox-active metals associated with protein; the reduced metal then donates this electron to

Address correspondence to: Joseph J. Cullen, M.D., 1528 JCP, Univ. of Iowa Hospitals and Clinics, Iowa City, IA 52242. josephcullen@uiowa.edu Office: (319) 353-8297, Fax: (319) 356-8378..

Declaration of Interest The authors declare that they have no competing interests. 
$\mathrm{O}_{2}$ forming superoxide radical that leads to formation of $\mathrm{H}_{2} \mathrm{O}_{2}$ [6]. Previous studies have shown that the oxidation of ascorbate occurs preferentially in the extracellular fluid [7]. Therefore, we propose that the $\mathrm{H}_{2} \mathrm{O}_{2}$ formed in the extracellular fluid diffuses into cells, leading to an increase in intracellular $\mathrm{H}_{2} \mathrm{O}_{2}$ and subsequent cytotoxicity. These previous studies have clearly demonstrated the increase in extracellular $\mathrm{H}_{2} \mathrm{O}_{2}$ with pharmacological ascorbate; however, direct evidence for ascorbate-induced changes in the intracellular level/ flux of $\mathrm{H}_{2} \mathrm{O}_{2}$ have been difficult to obtain. For example, the use of the oxidation sensitive 5(and-6)-carboxy-2 ${ }^{\prime}, 7^{\prime}$-dichlorodihydrofluorescein diacetate $\left(\mathrm{DCFH}_{2}\right)$ in assays that presumably measure intracellular $\mathrm{H}_{2} \mathrm{O}_{2}$ has many artifacts $[8,9,10]$. In addition ascorbate will reduce the free radical intermediate of the oxidation cascade of $\mathrm{DCFH}_{2}$ blunting the formation of DCF, the fluorescent oxidation product, thereby interfering with the detection of intracellular $\mathrm{H}_{2} \mathrm{O}_{2}$ [11].

There is a clear rationale for combining ascorbate with appropriate cytotoxic agents. Cells contain an antioxidant network to prevent or repair the damage caused by reactive oxygen species. Catalase and peroxidases remove $\mathrm{H}_{2} \mathrm{O}_{2}$, reducing it to water. Glutathione peroxidase (GPx) requires several co-factors and secondary enzymes. If removal of $\mathrm{H}_{2} \mathrm{O}_{2}$ generated by pharmacological ascorbate is inhibited, then pancreatic cancer cells should be more effectively killed because of direct toxicity resulting from $\mathrm{H}_{2} \mathrm{O}_{2}$-mediated damage. There are a number of compounds that can inhibit the removal of $\mathrm{H}_{2} \mathrm{O}_{2}$ by the antioxidant network. 1,3 bis (2-Chloroethyl)-1-nitrosurea (BCNU) is a clinically used chemotherapeutic agent that causes DNA alkylation but also inhibits glutathione disulfide reductase (GR) via carbamoylation. If GR is inhibited, cells have reduced ability to remove $\mathrm{H}_{2} \mathrm{O}_{2}$ via the glutathione peroxidase system. 2-Deoxy-D-glucose (2DG) is a relatively non-toxic analog of glucose that competes with glucose for uptake via the glucose transporters; it is phosphorylated by hexokinase at the entry point to glycolysis. Competition between 2DG and glucose is thought to cause inhibition of glucose metabolism, thereby creating a chemically induced state of glucose deprivation resulting in inhibition of hydroperoxide detoxification [12]. Combinations of these chemical inhibitors of glucose and hydroperoxide metabolism would be predicted to enhance ascorbate toxicity in tumor cells.

In this study, we used aminotriazole-mediated inhibition of endogenous catalase to determine ascorbate-induced changes in intracellular $\mathrm{H}_{2} \mathrm{O}_{2}$. We provide evidence that supports the proposal that the toxicity of pharmacological ascorbate is mediated by $\mathrm{H}_{2} \mathrm{O}_{2}$ formed from ascorbate oxidation. We demonstrate that chemical inhibitors of hydroperoxide detoxification further increase the level of intracellular $\mathrm{H}_{2} \mathrm{O}_{2}$ produced by pharmacological ascorbate thereby enhancing its toxicity.

\section{METHODS}

\section{Cell lines and chemicals}

The human pancreatic cancer cell line MIA PaCa-2 was cultured in DMEM high glucose supplemented with $10 \%$ FBS and $2.5 \%$ horse serum. Human pancreatic cancer AsPC-1 cells were maintained in RPMI 1640 medium supplemented with $20 \%$ FBS, sodium pyruvate $(1 \mathrm{mM})$, and $1 \%$ penicillin-streptomycin. Cells were maintained in a humidified atmosphere of $95 \%$ air $/ 5 \% \mathrm{CO}_{2}$ at $37^{\circ} \mathrm{C}$.

L-ascorbic acid was purchased from Macron Chemicals (Center Valley, PA). Stock solutions of ascorbate $(1.0 \mathrm{M})$ were made as previously described [13]. L-Ascorbic acid 2phosphate sesquimagnesium salt hydrate (A2P), 2-deoxy-glucose (2DG), 1,3-bis (2chloroethyl)-1-nitrosourea (BCNU), and 3-amino-1,2,4-triazole (3-AT) were purchased from Sigma (Sigma-Aldrich, St. Louis, MO). siRNA targeted against glutathione disulfide reductase was designed and manufactured by Ambion (Austin, TX). siRNA ID \#: s6249, 
sense (GUAUCACGCAGUUACCAAATT), antisense

(UUUGGUAACUGCGUGAUACAT); Silencer Select Negative control (Product \#: 4390843) was from Applied Biosystem (Foster City, CA). siNeg (siRNAs with sequences that do not target any gene product) was used to determine the transfection efficiency and to control for the effects of the siRNA delivery method. MIA PaCa- 2 cells were transfected with siRNA ( 20 pmole $/ 2 \times 10^{5}$ cells by Lipofectamine 2000, Invitrogen) for 24 hours. The cells were incubated in full media for specified times prior to experiments.

\section{Oxygen consumption rate (OCR) determination}

The rate of oxygen consumption by ascorbate $\left(\mathrm{AscH}^{-}\right)$oxidation was monitored using a BioStat ${ }^{\mathrm{TM}}$ multi-mode electrochemical system (ESA Biosciences, Chelmsford, MA) in conjunction with a Clark electrode (YSI oxygen probe 5331, Yellow Springs, OH). Three milliliters of DMEM growth media was transferred to the reaction chamber, stirring for 2 $\mathrm{min}$. After inserting the electrode, the baseline was recorded for $2 \mathrm{~min}$. Ascorbate $(2,5,10$ and $20 \mathrm{mM}$ ) was added to the reaction chamber using a gas tight Hamilton syringe. The oxygen consumption was monitored for 3 to $5 \mathrm{~min}$. Since the measurements are displayed in nanoamps (nA), the baseline measured in $\mathrm{nA}$ is equal to initial concentration of oxygen 258 $\mu \mathrm{M}$, at room temperature [14]. OCR was determined from the initial slope after introduction of $\mathrm{AscH}^{-}$.

\section{Determination of intracellular hydrogen peroxide}

Intracellular $\mathrm{H}_{2} \mathrm{O}_{2}$ concentrations were determined by analysis of the rate of aminotriazolemediated inactivation of endogenous catalase activity [15]. Catalase is irreversibly inactivated by aminotriazole (3-AT, 3-amino-1,2,4-triazole (Sigma)) in the presence of $\mathrm{H}_{2} \mathrm{O}_{2}$; following the rate of inactivation of intracellular catalase allows determination of the intracellular concentration of $\mathrm{H}_{2} \mathrm{O}_{2}$. Cells grown in 150-mm culture dishes were treated with ascorbate $(20 \mathrm{mM})$ in the presence of 3-AT $(20 \mathrm{mM})$ for $0,5,10,20,30,60$, and $120 \mathrm{~min}$ at $37^{\circ} \mathrm{C}$. Cells were washed with ice-cold PBS and harvested and lysed by freeze/thaw methodology. To determine the amount of fully active cellular catalase, cell lysate (2.00 $\mathrm{mL}$ ) was introduced into the reaction chamber of the oxygen monitor (YSI model 5300, YSI Inc., Yellow Springs, $\mathrm{OH}$ ). Then $333 \mu \mathrm{M}$ of $\mathrm{H}_{2} \mathrm{O}_{2}$ was injected into the reaction chamber and the rate of production of oxygen was continuously recorded for $5 \mathrm{~min}$ or until the curve reached a plateau. The rate of appearance of dioxygen reflects the amount of active catalase in the cell lysate. Cell protein was determined by Bio-Rad DC protein assay. The intracellular steady-state concentration of $\mathrm{H}_{2} \mathrm{O}_{2}$ was calculated from the equation $\left[\mathrm{H}_{2} \mathrm{O}_{2}\right]_{\mathrm{ss}}=$ $k_{\text {inactivation }} / k_{1}$ where $k_{\text {inactivation }}$ is the experimental pseudo first-order rate constant of catalase inactivation, and the value $k_{1}$ is $1.7 \times 10^{7} \mathrm{M}^{-1} \mathrm{~s}^{-1}$, the rate constant for the formation of catalase compound I.

\section{Intracellular GSH and GSSG determination}

Cells grown in 100-mm dishes were treated with ascorbate $(0,2,5,10$, and $20 \mathrm{mM})$ for 0,2 , 6 , and $24 \mathrm{~h}$. After treatment, cells were washed with PBS and harvested by trypsinization. Cells were placed in $5 \%$ perchloric acid/100 $\mu \mathrm{M}$ diethylenetriaminepentaacetic acid (DETAPAC; Sigma-Aldrich Chemical Co, St Louis, MO); this precipitates the protein and preserves glutathione (GSH) and glutathione disulfide (GSSG). The sample was centrifuged to pellet the protein $(4000 \mathrm{~g}, 5 \mathrm{~min})$. Supernatants were stored at $-80{ }^{\circ} \mathrm{C}$ or immediately analyzed. To determine the status of the GSSG, $2 \mathrm{H}^{+} / 2 \mathrm{GSH}$ couple in treated cells we used HPLC with electrochemical detection following the protocol outlined by Park et al. [16]. For the analysis, $20 \mu \mathrm{L}$ of each sample was injected and allowed to run for 1 hour. The method is based on an electrochemical detection (ECD) system using a boron-doped diamond (BDD) electrode (Model 5040, ESA Biosciences, Chelmsford, MA). The BDD electrode is 
an excellent detector for thiol and disulfide compounds as these analytes require a high electrode potential. Derivatization of the sample is not required allowing higher throughput. With the minimal sample processing required there is less opportunity for the sample to oxidize, which would lead to overestimation of GSSG [17]. The results from the HPLC/ BDD in conjunction with a cell count using a Z2 Coulter Counter ${ }^{\circledR}$ and the known intracellular volume (MIA PaCa-2: $2.0 \mathrm{pL}$ [14]) allow for the determination of the intracellular concentrations of GSH and GSSG. These concentrations in conjunction with the Nernst equation at room temperature conditions and $\mathrm{pH} 7.4$ were used to determine the intracellular half-cell reduction of the GSSG, $2 \mathrm{H}^{+} / 2 \mathrm{GSH}$ couple $\left(\mathrm{E}_{\mathrm{hc}}\right)$ [18].

\section{Glutathione disulfide reductase activity assay}

Cells treated with BCNU or siRNA against GR were harvested by trypsinization. Cell pellets were lysed in phosphate buffer. Glutathione reductase catalyzes NADPH-dependent reduction of GSSG to $2 \mathrm{GSH}$. The oxidation of NADPH to $\mathrm{NADP}^{+}$was monitored at $340 \mathrm{~nm}$ as an indicator of GR activity [19].

\section{Western blotting}

Cells were collected by scraping; protein concentrations were determined using a Bio-Rad DC Bradford Protein Assay (Bio-Rad Laboratories, Hercules, CA). Protein $(30 \mu \mathrm{g})$ was electrophoresed in a Bio-Rad 4-20\% Ready gel at $100 \mathrm{~V}$. The proteins were electrotransferred onto a PVDF membrane (Millipore, Billerica, CA) and blocked with $5 \%$ nonfat dry milk in Tween-PBS (TPBS) for $60 \mathrm{~min}$. The membranes were incubated with a rabbit polyclonal anti-glutathione reductase antibody (1:1000, Abcam, Cambridge, MA) at 4 ${ }^{\circ} \mathrm{C}$ overnight. Membranes were washed 5 times with $0.1 \%$ TPBS and incubated with secondary antibodies conjugated with horseradish peroxidase (1:50 000, CHEMICON International, Temecula, CA). GAPDH (1:5000, Millipore Corporation, Billerica, MA) was used as a loading control. After wash with TPBS, membranes were stained with Super Signal West Pico Chemiluminescent Substrate (Pierce Biotechnology, Rockford, IL) and exposed to Classic Blue Autoradiography Film (Molecular Technologies, St Louis, MO).

\section{Clonogenic assay}

Cells $\left(2 \times 10^{5}\right)$ were seeded in $60 \mathrm{~mm}$ culture dishes and treated $48 \mathrm{~h}$ later. After treatment, cells were trypsinized and seeded into 6-well plates at 400 cell/well in $4 \mathrm{~mL}$ growth media. Colonies formed between 10 to 14 days at $37^{\circ} \mathrm{C}$ were fixed with $70 \%$ ethanol and stained with Coomasie blue. Colonies with more than 50 cells were counted.

\section{Cell viability}

As an indicator of cell metabolic viability, the MTT assay was used. Cells were seeded at 1 $\times 10^{4}$ cells per well in a 96-well plate in full media. After $48 \mathrm{~h}$, cells were treated with ascorbate for $1 \mathrm{~h}$. For the cell viability experiments, all cell lines were treated in DMEM media for consistency. Then the cells were washed with PBS and incubated with fresh media for an additional $24 \mathrm{~h}$. MTT (3-[4,5-dimethylthiazol-2-yl]-2,5-diphenyltetrazolium bromide) (Sigma, St. Louis, MO) $1 \mathrm{mg} / \mathrm{mL}$ was added to the wells and incubated at $37^{\circ} \mathrm{C}$ for $3 \mathrm{~h}$. At the end of incubation, media was removed and $100 \mu \mathrm{L}$ of DMSO was added to each well for cell lysis. The plate was read at $590 \mathrm{~nm}$ on a Tecan SpectraFluor Plus plate reader (Tecan, Research Triangle Park, NC).

\section{Statistical Analysis}

Statistical analyses were performed by means of Systat (Systat Inc., Evanston Ill). A single factor ANOVA, followed by post-hoc Tukey test, was used to determine statistical differences between means. All means were calculated from at least three different 
experiments and error bars represent standard error of mean (SEM). All western blots were repeated at least twice and activity assays were performed in triplicate.

\section{RESULTS}

\section{Pharmacological ascorbate in the media increases OCR}

As shown in Table 1, the OCR of $2 \mathrm{mM}$ ascorbate in DMEM growth media was $61 \pm 12 \mathrm{nM}$ $\mathrm{s}^{-1}$ (no cells). Assuming all oxygen consumed upon oxidation of pharmacological ascorbate is converted to $\mathrm{H}_{2} \mathrm{O}_{2}$, then $\mathrm{H}_{2} \mathrm{O}_{2}$ was produced at the rate of $61 \pm 12 \mathrm{nM} \mathrm{s}^{-1}$. For $10 \times 10^{6}$ MIA PaCa- 2 cells grown in $10 \mathrm{~mL}$ media treated with $2 \mathrm{mM}$ ascorbate, each cell was exposed to $\mathrm{H}_{2} \mathrm{O}_{2}$ at the rate of $61 \times 10^{-18} \mathrm{~mol} \mathrm{cell}^{-1} \mathrm{~s}^{-1}$, i.e. $61 \mathrm{amol}$ cell $^{-1} \mathrm{~s}^{-1}$; for $20 \mathrm{mM}$ ascorbate, the rate was 334 amol cell ${ }^{-1} \mathrm{~s}^{-1}$. As context, the OCR of MiaPa-2 cells is $57 \mathrm{amol}$ cell ${ }^{-1} \mathrm{~s}^{-1}$ [14]. If $1 \%$ of this metabolicaly consumed oxygen is converted to $\mathrm{H}_{2} \mathrm{O}_{2}$, then the rate of metabolic production of $\mathrm{H}_{2} \mathrm{O}_{2}$ would be 0.6 amol cell ${ }^{-1} \mathrm{~s}^{-1}$. Thus, the flux of $\mathrm{H}_{2} \mathrm{O}_{2}$ per cell due to pharmacological ascorbate is on the order of 100 times that from metabolicly produced $\mathrm{H}_{2} \mathrm{O}_{2}$ in this experimental configuration. Thus, pharmacological ascorbate exposes cells to a very high flux of $\mathrm{H}_{2} \mathrm{O}_{2}$.

\section{Pharmacological ascorbate increases intracellular $\mathrm{H}_{2} \mathrm{O}_{2}$}

Pharmacological ascorbate has been shown to form $\mathrm{H}_{2} \mathrm{O}_{2}$ in extracellular media through the ascorbate radical intermediate [4]. We hypothesized that ascorbate-induced cytotoxicity is due to the formation of extracellular $\mathrm{H}_{2} \mathrm{O}_{2}$, which then diffuses into the cell and causes cytotoxicity as opposed to intracellular ascorbate oxidation. L-Ascorbate 2-phosphate (A2P) is a form of ascorbate that is protected from oxidation by the presence of a phosphate moiety. Although A2P is not a substrate of sodium-dependent vitamin $\mathrm{C}$ transporters (SVCTs), the phosphate group is most likely hydrolyzed by cell membrane esterases with the resulting ascorbate being transported into cells [20,21, 22]. The addition of A2P to cell culture media will increase intracellular ascorbate to millimolar levels [23]. Figure 1A shows that addition of A2P to treatment with pharmacological ascorbate does not enhance cytotoxicity. MIA PaCa- 2 cells treated with A2P $(100 \mu \mathrm{M})$ for $24 \mathrm{~h}$ showed no changes in clonogenic survival when compared to controls, while cells treated with ascorbate $(2 \mathrm{mM})$ had significant decreases in clonogenic survival. More importantly, clonogenic survival was similar in cells treated with the combination of A2P and ascorbate when compared to ascorbate alone. This suggests that increases in intracellular ascorbate are not responsible for ascorbate-induced cytotoxicity observed when ascorbate is added to the extracellular medium.

Previous studies have demonstrated that pharmacological ascorbate increases extracellular $\mathrm{H}_{2} \mathrm{O}_{2}$ generation [5]. To determine changes in intracellular $\mathrm{H}_{2} \mathrm{O}_{2}$ following exposure to pharmacological ascorbate we measured aminotriazole-mediated inactivation of endogenous catalase. We hypothesized that ascorbate would cause an increase in intracellular $\mathrm{H}_{2} \mathrm{O}_{2}$, thereby enhancing cytotoxicity. As shown in Figure 1B, MIA PaCa-2 cells treated with ascorbate $(20 \mathrm{mM})$ for $1 \mathrm{~h}$ demonstrated a significant increase in intracellular $\mathrm{H}_{2} \mathrm{O}_{2}$ as determined by the rate of inactivation of intracellular catalase. Control cells had steady-state concentrations of $\mathrm{H}_{2} \mathrm{O}_{2}$ of $43 \pm 5 \mathrm{pM}$, which increased to $71 \pm 15 \mathrm{pM}$ with ascorbate (20 $\mathrm{mM})(n=3, P<0.05)$.

\section{Ascorbate leads to oxidation of the GSSG/2GSH couple}

Increases in intracellular $\mathrm{H}_{2} \mathrm{O}_{2}$ may lead to changes in the redox state of the intracellular redox buffer. Peroxide-induced oxidative stress can cause a decrease in the amount of intracellular GSH and an increase in GSSG [24, 25]. We hypothesized that treatment with ascorbate would increase intracellular $\mathrm{H}_{2} \mathrm{O}_{2}$ leading to a decrease in intracellular GSH and 
changes in the important GSSG/2GSH redox couple. Indeed, our results show a time- and dose-dependent decrease in intracellular GSH (Figure 2) when cells are exposed to ascorbate $(2 \mathrm{mM}$ ) for $0,2,6$, and $24 \mathrm{~h}$. As the time of exposure to ascorbate increased, the half-cell reduction potential $\left(\mathrm{E}_{\mathrm{hc}}\right)$ of the GSSG/2GSH couple became more oxidized (Figure $2 \mathrm{~B}$ ). In addition, when MIA PaCa- 2 cells were exposed to varying concentrations of extracellular ascorbate $(2,5,10$, and $20 \mathrm{mM}$ ), the intracellular concentration of GSH decreased (Figure 2C) with a concomitant increase in $\mathrm{E}_{\mathrm{hc}}$, i.e. GSSG/2GSH couple became more oxidized (Figure 2D). These results further demonstrate that exposure of cells to high levels of extracellular ascorbate induces intracellular oxidative stress by increasing intracellular $\mathrm{H}_{2} \mathrm{O}_{2}$.

\section{Inhibitors of peroxide metabolism enhance ascorbate-induced cytotoxicity and intracellular $\mathrm{H}_{2} \mathrm{O}_{2}$ levels}

Ascorbate can be cytotoxic to pancreatic cancer cells, and this cytotoxicity is most likely due to an $\mathrm{H}_{2} \mathrm{O}_{2}$-mediated mechanism [5]. We hypothesized that using inhibitors of $\mathrm{H}_{2} \mathrm{O}_{2}$ metabolism would enhance ascorbate-induced cytotoxicity by increasing the levels of $\mathrm{H}_{2} \mathrm{O}_{2}$ in the cell. 1,3-bis-Chloroethyl-1-nitrosourea (BCNU) is a chemotherapy drug that decomposes in aqueous buffer at physiological $\mathrm{pH}$ to form an alkylating moiety and a carbamoylation moiety. The alkylating moiety reacts in the cell to alkylate purines or pyrimidines, resulting in DNA and RNA cross-linking. The carbamoylation moiety acts on nucleophilic alkyl side chain groups of amino acids inactivating proteins, including glutathione disulfide reductase [26, 27]. After exposure to BCNU, cells increase the synthesis of new glutathione (GSH) [28] and also increase the percentage of glutathione disulfide (GSSG) [29], most likely due to the inactivation of GR, which reduces GSSG to GSH. If GR is inhibited, the ability of cells to remove hydrogen peroxide will be compromised. Pretreatment of MIA PaCa-2 cells with BCNU decreases GR activity in a dose-dependent manner (Figure 3A). Additionally, BCNU $(25 \mu \mathrm{M})$ decreases GR activity in a time-dependent manner (Figure 3B). Cells treated with BCNU $(25 \mu \mathrm{M})$ alone had no effect on clonogenic survival (Figure 3C). However, the combination of BCNU and ascorbate $(2 \mathrm{mM})$ dramatically decreased clonogenic survival $(n=3, * P<0.001 \mathrm{vs}$. control, $* * P<0.001 \mathrm{vs}$. ascorbate). The combination of BCNU and ascorbate had similar effects in another pancreatic cancer cell line, AsPC-1 (Figure 3D). Plating efficiency was $44 \pm 2$ in control cells and decreased to $8 \pm 1$ with ascorbate $(2 \mathrm{mM})$ and $13 \pm 1$ with BCNU $(25 \mu \mathrm{M})$. However, the combination of ascorbate and BCNU further decreased plating efficiency to 2 \pm 1 ( $n=3, * P<0.001$ vs. control, $* * P<0.05$ vs. ascorbate). The MTT assay also demonstrated significant decreases in cell viability when MIA PaCa-2 and AsPC-1 cells were treated with the combination of ascorbate and BCNU. Ascorbate decreased viability to $15 \pm 0.1 \%$ of control while the combination of ascorbate and BCNU further decreased viability to $10 \pm 0.1 \%\left(n=4,{ }^{*} P<0.01 \mathrm{vs}\right.$. control, $* * P<0.05 \mathrm{Vs}$. ascorbate) (Figure 3E).

As mentioned, BCNU has other effects in addition to inhibition of GR. To determine if changes in the activity of GR alone can modulate clonogenic survival, we used siRNA targeted to GR (Figure 4). MIA PaCa-2 cells transfected with siGR demonstrated decreases in GR protein compared to the siNegative control (Figure 4A). In addition, GR activity assays demonstrated $>50 \%$ decrease in GR activity in cells treated with siGR (Figure 4B). After demonstrating that the siGR reduced the amount GR protein and decreased overall activity, a clonogenic survival assay was performed. Cells transfected with siGR had similar clonogenic survival when compared to controls. Ascorbate $(2 \mathrm{mM})$ decreased clonogenic survival from $23 \pm 0.3 \%$ to $7 \pm 0.1 \%(n=3, P<0.001)$. In contrast, the combination of ascorbate and siGR enhanced the cytotoxicity of ascorbate leading to a further decrease in clonogenic survival down to $2.5 \pm 0.5 \%$ ( $P<0.001$ compared to ascorbate alone, Figure 4C). 
2-Deoxy-D-glucose (2DG) is thought to cause inhibition of glucose metabolism and the pentose phosphate pathway, thereby creating a chemically induced state of glucose deprivation resulting in inhibition of hydroperoxide detoxification due to decreased NADPH [12]. When MIA PaCa-2 cells were treated with 2DG $(25 \mathrm{mM})$ for $1 \mathrm{~h}$ clonogenic survival was similar to controls (controls $48 \pm 4 \% ; 2 \mathrm{DG} 40 \pm 0.1 \%$ ), Figure 5A. Treatment of cells with ascorbate $(2 \mathrm{mM})$ decreased clonogenic survival to $22 \pm 2 \%$. However, the combination of ascorbate and 2DG enhanced these effects, resulting in clonogenic survival of only $0.5 \pm 0.1 \%(n=3, P<0.001)$. Similar results were seen in AsPC-1 cells as the combination of ascorbate and 2DG enhanced ascorbate-induced cytotoxicity (Figure 5B). Significant decreases in cell viability were also demonstrated when MIA PaCa-2 and AsPC-1 cells were treated with the combination of ascorbate and 2DG. Ascorbate decreased viability to $15 \pm 0.1 \%$ of control while the combination of ascorbate and 2DG further decreased viability to $10 \pm 0.1 \%(n=4, * P<0.05 \mathrm{vs}$. control, $* * P<0.05 \mathrm{vs}$. ascorbate) (Figure 5C). Taken together with the mechanism of 2DG-induced inhibition of hydroperoxide inhibition, these results are consistent with the hypothesis that $\mathrm{H}_{2} \mathrm{O}_{2}$ is a key species responsible for the toxic effects of pharmacological ascorbate.

To further elucidate the mechanism of ascorbate-induced cytotoxicity, cells were treated with a scavenger of $\mathrm{H}_{2} \mathrm{O}_{2}$, pyruvate; indeed, pyruvate rescues MIA PaCa-2 cells from ascorbate-induced cytotoxicity, Figure 5D. MIA PaCa-2 cells treated with ascorbate $(2 \mathrm{mM})$ showed a significant decrease in clonogenic survival from $49 \pm 3 \%$ to $20 \pm 0.5 \%(n=3, P$ $<0.001)$. However, pyruvate reversed ascorbate-induced cytotoxicity, while treatment with pyruvate alone $(5 \mathrm{mM})$ had little effect on clonogenic survival. Again, these observations are consistent with a peroxide-mediated mechanism for the toxicity of pharmacological ascorbate.

Since exposure of cells to pharmacological ascorbate leads to an increase in intracellular $\mathrm{H}_{2} \mathrm{O}_{2}$ and inhibitors of peroxide-removal enhance ascorbate-induced cytotoxicity, we hypothesized that inclusion of inhibitors of $\mathrm{H}_{2} \mathrm{O}_{2}$ metabolism while cells were exposed to pharmacological ascorbate would further increase intracellular $\mathrm{H}_{2} \mathrm{O}_{2}$. We determined the changes in intracellular $\mathrm{H}_{2} \mathrm{O}_{2}$ that accompany treatments with inhibitors of $\mathrm{H}_{2} \mathrm{O}_{2}$ metabolism through the use of aminotriazole-mediated inactivation of endogenous catalase, Figure 5E. BCNU $(25 \mu \mathrm{M})$ combined with ascorbate $(20 \mathrm{mM})$ increased intracellular $\mathrm{H}_{2} \mathrm{O}_{2}$ by $35 \mathrm{pM}$ compared to cells treated with BCNU only $(P<0.001)$. Treatment with siRNA against GR in addition to ascorbate significantly increased intracellular $\mathrm{H}_{2} \mathrm{O}_{2}$ by $47 \mathrm{pM}$ over cells treated with siRNA against GR only $(P<0.05)$. MIA PaCa- 2 cells treated with 2DG $(25 \mathrm{mM})$ and ascorbate $(20 \mathrm{mM})$ for $1 \mathrm{~h}$ also showed a significant increase in intracellular $\mathrm{H}_{2} \mathrm{O}_{2}$ by $85 \mathrm{pM}$ when compared with cells that were treated with $2 \mathrm{DG}$ alone $(P<0.05)$. These data demonstrate that inhibitors of $\mathrm{H}_{2} \mathrm{O}_{2}$ metabolism enhance the increase in the intracellular steady-state concentration of $\mathrm{H}_{2} \mathrm{O}_{2}$ caused by pharmacological ascorbate.

Pharmacological ascorbate increases intracellular $\mathrm{H}_{2} \mathrm{O}_{2}$. Pyruvate $(5 \mathrm{mM})$ negated the increase in intracellular $\mathrm{H}_{2} \mathrm{O}_{2}$ seen upon exposure of cells to extracellular ascorbate (20 $\mathrm{mM}$ ), Figure 5F. Consistent with this we found that pyruvate also reversed ascorbateinduced cytotoxicity, Figure 5D. These observations indicate that under our experimental conditions, extracellular $\mathrm{H}_{2} \mathrm{O}_{2}$ produced by the oxidation of pharmacological ascorbate is the primary species responsible for the observed cytotoxicity. This $\mathrm{H}_{2} \mathrm{O}_{2}$ diffuses into cells where it is removed by the intracellular antioxidant system. Agents that enhance peroxide removal, e.g. pyruvate, are protective; agents that inhibit intracellular peroxide removal sensitize cells to exposure pharmacological ascorbate. 


\section{DISCUSSION}

Recent studies have demonstrated that pharmacological ascorbate induces cytotoxicity in pancreatic cancer cells and maybe a potential treatment for pancreatic cancer [5, 30]. Our previous studies suggested that ascorbate-induced cytotoxicity is due to an $\mathrm{H}_{2} \mathrm{O}_{2}$-mediated mechanism, where $\mathrm{H}_{2} \mathrm{O}_{2}$ is formed in the extracellular fluid and diffuses into the cell, resulting in cytotoxicity [5]. Utilizing a reliable kinetic assay for the intracellular concentration of $\mathrm{H}_{2} \mathrm{O}_{2}$, i.e. the aminotriazole-mediated inactivation of endogenous catalase, we were able to measure ascorbate-induced changes in intracellular $\mathrm{H}_{2} \mathrm{O}_{2}$. Taken together with our previous studies $[4,5]$, our current findings suggest that ascorbate oxidizes extracellularly producing $\mathrm{H}_{2} \mathrm{O}_{2}$, which diffuses into the cell to cause cytotoxicity. Using A2P, a form of ascorbate that increases intracellular ascorbate but does not oxidize in cell culture media, we demonstrated that increases of intracellular ascorbate did not attenuate the effect of extracellular ascorbate-induced cytotoxicity. We further demonstrated that the $\mathrm{H}_{2} \mathrm{O}_{2}$ produced by ascorbate extracellularly diffuses into the cell to induce cytotoxicity. Most importantly, our results showed that treatment of ascorbate (extracellular) increases the levels of intracellular $\mathrm{H}_{2} \mathrm{O}_{2}$. Consistent with our hypothesis, addition of pyruvate, a compound that scavenges $\mathrm{H}_{2} \mathrm{O}_{2}$, reversed ascorbate-induced increases in intracellular $\mathrm{H}_{2} \mathrm{O}_{2}$ as well as rescues cells from ascorbate-induced cytotoxicity. Additionally we demonstrated that increased levels of peroxide lead to oxidation of the intracellular redox buffer; intracellular GSH decreases in a dose- and time-dependent manner. Thus, ascorbate-induced generation of $\mathrm{H}_{2} \mathrm{O}_{2}$ leads to toxicity through an oxidative stress mechanism.

Due to ascorbate's role in the increase in intracellular $\mathrm{H}_{2} \mathrm{O}_{2}$, augmentation of the intracellular $\mathrm{H}_{2} \mathrm{O}_{2}$ concentration could potentially enhance cytotoxicity to pancreatic cancer cells. One method that can be used to increase the intracellular concentration of $\mathrm{H}_{2} \mathrm{O}_{2}$ is to inhibit peroxide removal. The GPx system is an important system in the detoxification of peroxide, and GR is an essential enzyme in this system [31]. We demonstrated that inhibiting GR with BCNU or siGR reduces the cell's ability to remove $\mathrm{H}_{2} \mathrm{O}_{2}$. Likewise, the GR system is dependent on glucose, and using 2DG, a competitive inhibitor of glucose, prevents the removal of $\mathrm{H}_{2} \mathrm{O}_{2}$. Our results showed that the combination of inhibitors of peroxide detoxification with ascorbate increased intracellular $\mathrm{H}_{2} \mathrm{O}_{2}$ concentration and increased cytotoxicity. Interesting for future research will be the targeting of the thioredoxin/ peroxiredoxin node of the peroxide removal system to determine if the cytotoxicity induced by this $\mathrm{H}_{2} \mathrm{O}_{2}$ can be increased further.

Besides inhibition of GR via carbamoylation, BCNU also causes DNA or RNA crosslinking via alkylation. Thus, the dual effect of $\mathrm{BCNU}$ on enhanced cell killing may be due to the alkylating effect, as well as (or instead of) the inhibition of GR. In support of the carbamoylation effect of BCNU and subsequent inhibition of GR, Nathan and Cohn demonstrated that $\mathrm{BCNU}$ could enhance the antitumor effect of $\mathrm{H}_{2} \mathrm{O}_{2}$ [32]. Other methods to enhance cancer cell toxicity by increasing intracellular peroxide include increased expression of manganese superoxide dismutase (MnSOD) [33]. Elevating the MnSOD activity in cells can increase the intracellular flux of superoxide $\left(\mathrm{O}_{2}{ }^{-}\right)$and subsequently $\mathrm{H}_{2} \mathrm{O}_{2}$ [33]. Inhibition of the GR activity in cells by BCNU resulted in inhibition of peroxide removal through the GPx pathway [34]. Zhong et al. [34] demonstrated a significant correlation between the sensitivity of glioma cells to BCNU and catalase levels suggesting that inhibition of the glutathione system shifts the burden to catalase for protecting against peroxide toxicity.

In summary, treatment of pancreatic cancer cells with pharmacological ascorbate results in extracellular generation of $\mathrm{H}_{2} \mathrm{O}_{2}$; this $\mathrm{H}_{2} \mathrm{O}_{2}$ diffuses into the cell resulting in an increase in intracellular $\mathrm{H}_{2} \mathrm{O}_{2}$ and cytotoxicity. Exciting is that inhibitors of $\mathrm{H}_{2} \mathrm{O}_{2}$ removal can enhance 
the cytotoxicity pharmacological ascorbate. Thus, treatments consisting of a combination of ascorbate and inhibitors of the removal of $\mathrm{H}_{2} \mathrm{O}_{2}$ may potentially be an effective therapy for pancreatic adenocarcinoma. Pharmacological ascorbate in combination with appropriate adjuvants appears to be an immediately available and more clinically applicable treatment of pancreatic adenocarcinoma at this time compared to gene-directed therapies in their current state of development.

\section{Acknowledgments}

This research was supported by NIH grant U01 CA166800, the Department of Veterans Affairs Medical Research Service, and the Susan L. Bader Foundation of Hope. TJvE had support from NIH P42 ES013661, Training Core; JRW had support from NIH T32CA078586 and NIH R01GM073929. The content is solely the responsibility of the authors and does not represent views of the Department of Veterans Affairs or the NIH.

\section{REFERENCES}

1. Levine M, Padayatty SJ, Espey MG. Vitamin C: a concentration-function approach yields pharmacology and therapeutic discoveries. Adv Nutr. 2011; 2(2):78-88. [PubMed: 22332036]

2. Padayatty SJ, Sun H, Wang Y, Riordan HD, Hewitt SM, Katz A, et al. Vitamin C pharmacokinetics: implications for oral and intravenous use. Ann Intern Med. 2004; 140(7):533-537. [PubMed: 15068981]

3. Hoffer LJ, Levine M, Assouline S, Melnychuk D, Padayatty SJ, Rosadiuk K, et al. Phase I clinical trial of i.v. ascorbic acid in advanced malignancy. Ann Oncol. 2008; 19(11):1969-1974. [PubMed: 18544557]

4. Chen Q, Espey MG, Krishna MC, Mitchell JB, Corpe CP, Buettner GR, et al. Pharmacologic ascorbic acid concentrations selectively kill cancer cells: action as a pro-drug to deliver hydrogen peroxide to tissues. Proc Natl Acad Sci U S A. 2005; 102:13604-13609. [PubMed: 16157892]

5. Du J, Martin SM, Levine M, Wagner BA, Buettner GR, Wang SH, et al. Mechanisms of ascorbateinduced cytotoxicity in pancreatic cancer. Clin Cancer Res. 2010; 16:509-520. [PubMed: 20068072]

6. Du J, Cullen JJ, Buettner GR. Ascorbic acid: Chemistry, biology and the treatment of cancer. Biochim Biophys Acta. 2012; 1826:443-557. [PubMed: 22728050]

7. Chen Q, Espey MG, Sun AY, Lee JH, Krishna MC, Shacter E, et al. Ascorbate in pharmacologic concentrations selectively generates ascorbate radical and hydrogen peroxide in extracellular fluid in vivo. Proc Natl Acad Sci U S A. 2007; 104:8749-8754. [PubMed: 17502596]

8. Hempel SL, Buettner GR, O'Malley YQ, Wessels DA, Flaherty DM. Dihydrofluorescein diacetate is superior for detecting intracellular oxidants: comparison with 2',7'-dichlorodihydrofluorscein diacetate, 5(and 6)-carboxy-2',7'-dichlorodihydrofluorscein diacetate, and dihydrorhodamine 123. Free Radic Biol Med. 1996; 27:146-159. [PubMed: 10443931]

9. Kalyanaraman B, Darley-Usmar V, Davies KJ, Dennery PA, Forman HJ, Grisham MB, et al. Measuring reactive oxygen and nitrogen species with fluorescent probes: challenges and limitations. Free Radic Biol Med. 2012; 52:1-6. [PubMed: 22027063]

10. Bonini MG, Rota C, Tomasi A, Mason RP. The oxidation of 2',7'-dichlorofluorscein to reactive oxygen species: A self-fulfilling prophesy? Free Radic Biol Med. 2006; 40:968-975. [PubMed: 16540392]

11. Rota C, Fann YC, Mason RP. Phenoxyl free radical formation during the oxidation of the fluorescent dye 2',7'-dichlorofluorescein by horseradish peroxidase. Possible consequences for oxidative stress measurements. J Biol Chem. 1999; 274:28161-28168. [PubMed: 10497168]

12. Coleman MC, Asbury C, Daniels DH, Du J, Smith BJ, Li L, et al. Inhibition of glucose metabolism in pancreatic cancer induces cytotoxicity via metabolic oxidative stress. Free Radic Biol Med. 2008; 44:322-332. [PubMed: 18215740]

13. Buettner GR. In the absence of catalytic metals, ascorbate does not autoxidize at $\mathrm{pH} 7$ : Ascorbate as a test for catalytic metals. J Biochem Biophys Meth. 1988; 16:27-40. [PubMed: 3135299]

14. Wagner BA, Venkataraman S, Buettner GR. The rate of oxygen utilization by cells. Free Radic Biol Med. 2011; 51:700-712. [PubMed: 21664270] 
15. Royall JA, Gwin PD, Parks DA, Freeman BA. Responses of vascular endothelial oxidant metabolism to lipopolysaccharide and tumor necrosis factor-alpha. Arch Biochem Biophys. 1992; 294:686-694. [PubMed: 1567224]

16. Park HJ, Mah E, Bruno RS. Validation of high-performance liquid chromatography-boron-doped diamond detection for assessing hepatic glutathione redox status. Anal Biochem. 2010; 407(2): 151-159. [PubMed: 20705049]

17. Jones DP, Liang Y. Measuring the poise of thiol/disulfide couples in vivo. Free Radic Biol Med. 2009; 47(10):1329-38. [PubMed: 19715755]

18. Schafer FQ, Buettner GR. Redox environment of the cell as viewed through the redox state of the glutathione disulfide/glutathione couple. Free Radic Biol Med. 2001; 30(11):1191-1212. [PubMed: 11368918]

19. Carlberg I, Mannervik B. Glutathione reductase. Methods in Enzymology. 1985; 113:484-490. [PubMed: 3003504]

20. Frikke-Schmidt H, Lykkesfeldt J. Keeping the intracellular vitamin C at a physiologically relevant level in endothelial cell culture. Anal Biochem. 2010; 397:135-137. [PubMed: 19782654]

21. Chepda T, Cadau M, Girin P, Frey J, Chamson A. Monitoring of ascorbate at a constant rate in cell culture: effect on cell growth. In Vitro Cell Dev Biol Anim. 2001; 37:26-30. [PubMed: 11249202]

22. Fujiwara M, Nagao N, Monden K, Misumi M, Kageyama K, Miwa N. Enhanced protectionagainst peroxidation-induced mortality of aortic endothelial cells by ascorbic acid-2-O-phosphate abundantly accumulated in the cell as the dephosphorylated form. Free Radic Res. 1997; 27:97104. [PubMed: 9269584]

23. Vislisel JM, Schafer FQ, Buettner GR. A simple and sensitive assay for ascorbate using a plate reader. Anal Biochem. 2007; 365:31-39. [PubMed: 17433246]

24. Townsend DM, Tew KD, Tapiero H. The importance of glutathione in human disease. Biomed Pharmacother. 2003; 57:145-155. [PubMed: 12818476]

25. Pastore A, Federici G, Bertini E, Piemonte F. Analysis of glutathione: implication in redox and detoxification. Clin Chim Acta. 2003; 333:19-39. [PubMed: 12809732]

26. Arscott LD, Gromer S, Schirmer RH, Becker K, Williams CH Jr. The mechanism of thioredoxin reductase from human placenta is similar to the mechanisms of lipoamide dehydrogenase and glutathione reductase and is distinct from the mechanism of thioredoxin reductase from Escherichia coli. Proc Natl Acad Sci U S A. 1997; 94:3621-3626. [PubMed: 9108027]

27. Frischer H, Kennedy EJ, Chigurupati R, Sivarajan M. Glutathione, cell proliferation, and 1,3-bis(2-chloroethyl)-1-nitrosourea in K562 leukemia. J Clin Invest. 1993; 92:2761-2767. [PubMed: 8254030]

28. Kirsch JD, Yi AK, Spitz DR, Krieg AM. Accumulation of glutathione disulfide mediates NF-kB activation during immune stimulation with CpG DNA. Antisense Nucleic Acid Drug Dev. 2002; 12:327-340. [PubMed: 12477282]

29. Babson JR, Reed DJ. Inactivation of glutatione reductase by 2-chloroethyl nitrosourea-derived isocyanates. Biochem Biophys Res Commun. 1978; 83:754-762. [PubMed: 358985]

30. Espey MG, Chen P, Chalmers B, Drisko J, Sun AY, Levine M, et al. Pharmacologic ascorbate synergizes with gemcitabine in preclinical models of pancreatic cancer. Free Radic Biol Med. 2011; 50(11):1610-1619. [PubMed: 21402145]

31. Weydert CJ, Zhang Y, Sun W, Waugh TA, Teoh ML, Andringa KK, et al. Increased oxidative stress created by adenoviral MnSOD or CuZnSOD plus BCNU (1,3-bis(2-chloroethyl)-1nitrosourea) inhibits breast cancer cell growth. Free Radic Biol Med. 2008; 44:856-867. [PubMed: 18155673]

32. Nathan CF, Cohn ZA. Antitumor effects of hydrogen peroxide in vivo. J Exp Med. 1981; 154:1539-1553. [PubMed: 7299347]

33. Buettner GR, Ng CF, Wang M, Rodgers VG, Schaefer FQ. A new paradigm: manganese superoxide dismutase influences the production of $\mathrm{H}_{2} \mathrm{O}_{2}$ in cells and thereby their biological state. Free Radic Biol Med. 2006; 41:1338-1350. [PubMed: 17015180]

34. Zhong W, Yan T, Lim R, Oberley LW. Expression of superoxide dismutases, catalase, and glutathione peroxidase in glioma cells. Free Radic Biol Med. 1999; 27:1334-1345. [PubMed: 10641728] 
A.

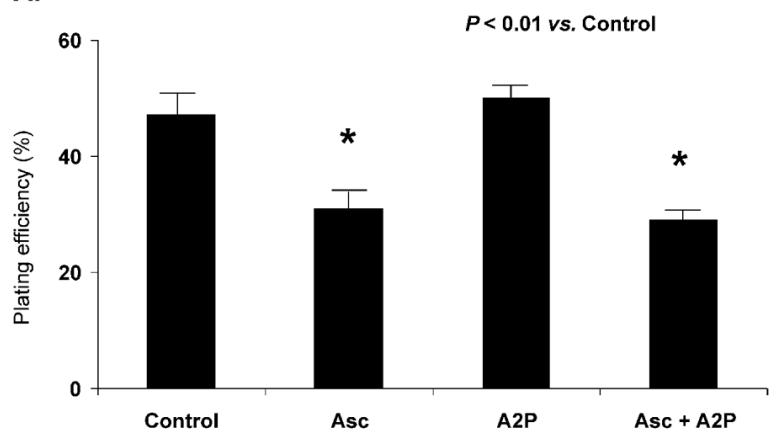

B.

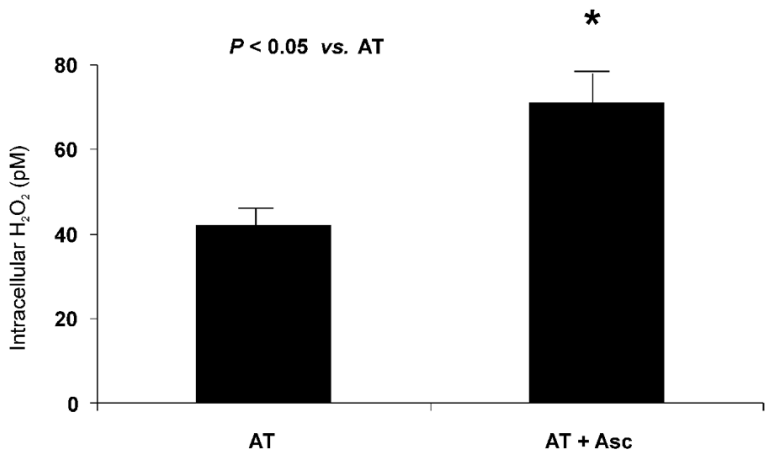

Figure 1. Ascorbate increases intracellular concentration of $\mathrm{H}_{2} \mathrm{O}_{2}$

A. MIA PaCa-2 cells were treated with L-ascorbate 2-phosphate ([A2P] $=100 \mu \mathrm{M})$ for $24 \mathrm{~h}$ and ascorbate $(2 \mathrm{mM})$ for $1 \mathrm{~h}$ and clonogenic survival was determined. A combination of A2P $(100 \mu \mathrm{M})$ and ascorbate $(2 \mathrm{mM})$ did show a significant decrease in survival compared to controls. ( $* P<0.01$ vs. control, means \pm SEM, $n=3$ ). However, this treatment did not show significant decreases in clonogenic survival when compared to ascorbate-treated cells, suggesting that increased intracellular ascorbate levels were not responsible for ascorbateinduced cytotoxicity under our experimental conditions.

B. MIA PaCa-2 cells were treated with $20 \mathrm{mM}$ ascorbate in the presence of $20 \mathrm{mM}$ aminotriazole (AT) and the concentration of intracellular $\mathrm{H}_{2} \mathrm{O}_{2}$ was determined using aminotriazole-mediated inactivation of endogenous catalase. Cells treated with ascorbate showed a significant $66 \%$ increase in intracellular $\mathrm{H}_{2} \mathrm{O}_{2}$ when compared to cells that were treated with AT only, $* P<0.05$ vs. AT, means \pm SEM, $n=4$. 


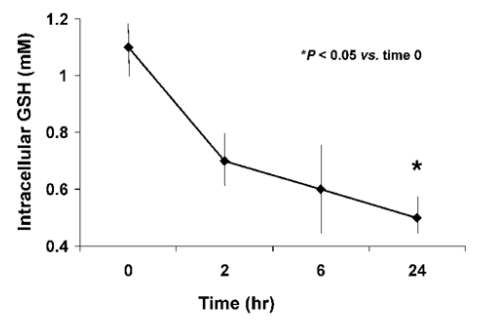

c.

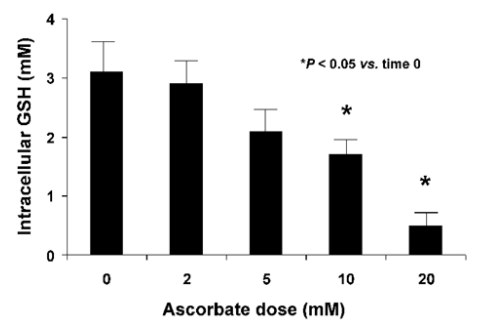

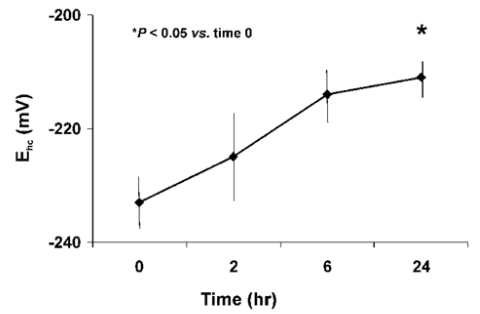

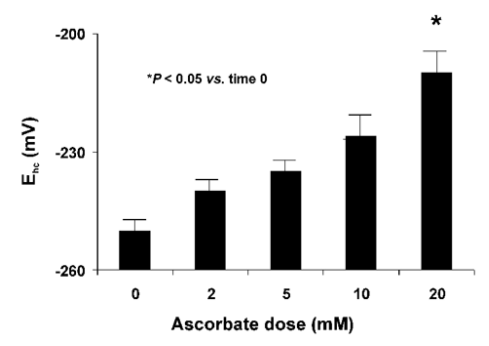

Figure 2. Ascorbate treatment induces oxidative stress

A. MIA PaCa-2 cells were treated with ascorbate $(2 \mathrm{mM})$ for $0,2,6$, and $24 \mathrm{~h}$ and intracellular GSH levels were measured. Ascorbate $(2 \mathrm{mM})$ treatment decreases intracellular GSH. $* P<0.05$ vs. the 0 time point, means \pm SEM, $n=3$.

B. Ascorbate $(2 \mathrm{mM})$ increases (more positive) the intracellular half-cell reduction potential $\left(\mathrm{E}_{\mathrm{hc}}\right)$ of the intracellular GSSG/2GSH couple (intracellular redox buffer) of MIA PaCa-2 cells, a clear indication of increased intracellular oxidations. $* P<0.05 \mathrm{Vs}$. the 0 time point, means \pm SEM, $n=3$.

C. Intracellular GSH decreases with increasing concentrations of extracellular ascorbate (2 $20 \mathrm{mM}$ for 1 hour). $* P<0.05$ vs. the $0 \mathrm{mM}$ dose, means \pm SEM, $n=3$.

D. The half-cell reduction potential of MIA PaCa- 2 cells increases in a dose-dependent manner demonstrating ascorbate-induced oxidation. ${ }^{*} P<0.05 \mathrm{Vs}$. the $0 \mathrm{mM}$ dose, means \pm SEM, $n=3$. 


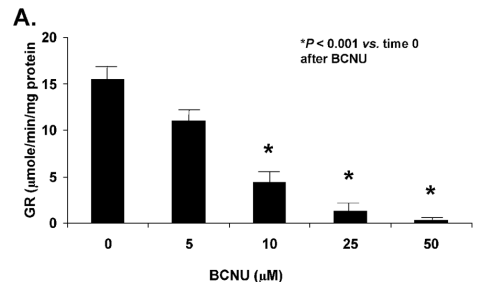

c.

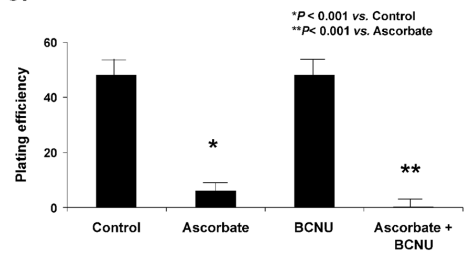

E.

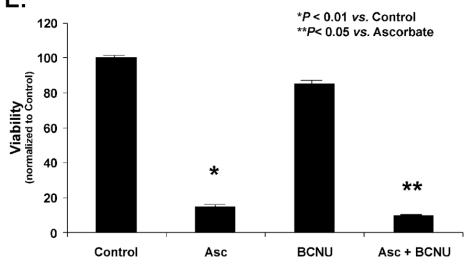

B.

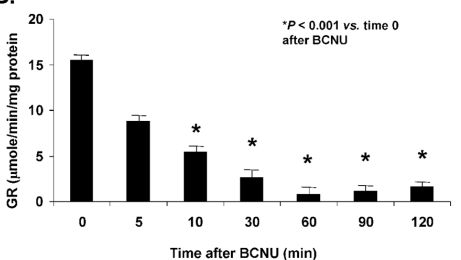

D.

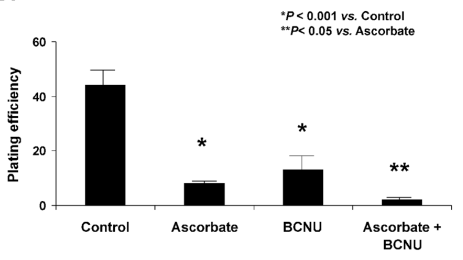

Figure 3. BCNU enhances ascorbate-induced cytotoxicity through the inhibition of glutathione disulfide reductase

A. BCNU decreases the activity of glutathione disulfide reductase in a dose-dependent manner. * $P<0.05$ vs. the BCNU $0 \mu \mathrm{M}$ dose, means $\pm \mathrm{SEM}, n=3$.

B. MIA PaCa- 2 cells treated with BCNU $(25 \mu \mathrm{M})$ showed decreasing activity of GR over time. $* P<0.05 v s$. the BCNU $0 \mu \mathrm{M}$ dose, means \pm SEM, $n=3$.

C. MIA PaCa- 2 cells were treated with BCNU $(25 \mu \mathrm{M}, 2 \mathrm{~h})$ and ascorbate $(2 \mathrm{mM}, 1 \mathrm{~h})$ and clonogenic survival was determined. Ascorbate caused a decrease in clonogenic survival, $* P$ $<0.001$ vs. control, mean $\pm \mathrm{SEM}, n=3$.

D. AsPC-1 cells were treated with BCNU $(25 \mu \mathrm{M})$ and ascorbate $(2 \mathrm{mM})$ and clonogenic survival was determined. Ascorbate caused a decrease in clonogenic survival, $* P<0.001$ vs. control, mean \pm SEM, $n=3$.

E. MIA PaCa- 2 cells were treated with BCNU $(25 \mu \mathrm{M}, 2 \mathrm{~h})$ and ascorbate $(2 \mathrm{mM}, 1 \mathrm{~h})$ and cell viability with a MTT assay was determined. Ascorbate caused a decrease in cell viability, ${ }^{*} P<0.01$ Vs. control, mean \pm SEM, $n=4$. Treatment with BCNU alone showed no significant effect on cytotoxicity, but a combination of BCNU and ascorbate enhanced ascorbate-induced cytotoxicity, ${ }^{* *} P<0.05 \mathrm{VS}$. ascorbate, means \pm SEM, $n=4$. Similar trends were seen with AsPC-1 cells treated with ascorbate \pm BCNU (data not shown). 
A.
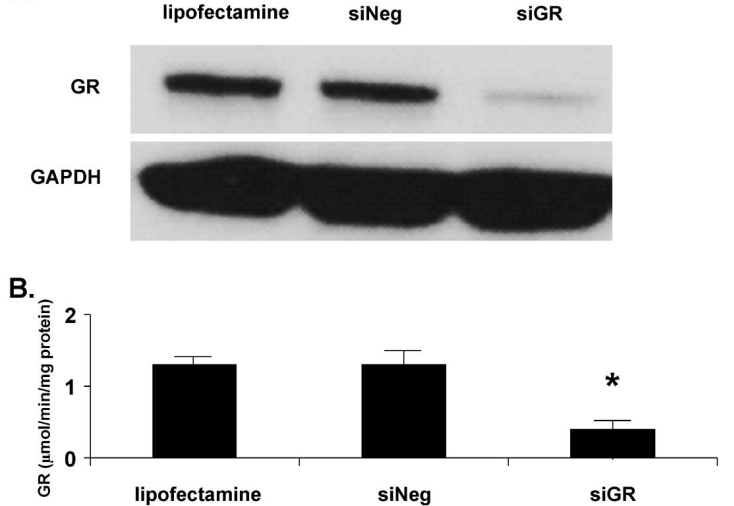

C.

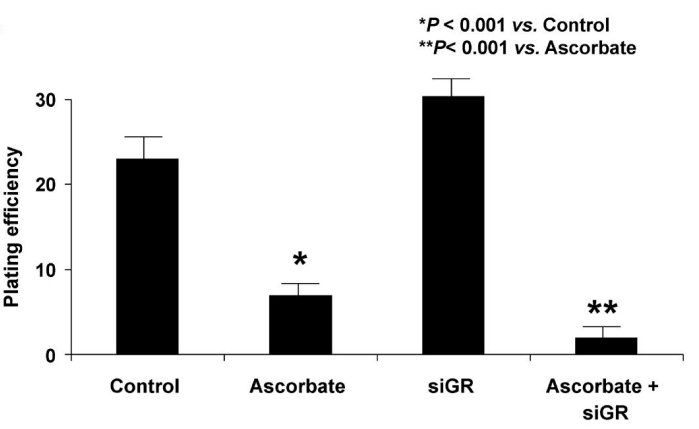

Figure 4. siRNA to GR enhances ascorbate-induced cytotoxicity

A. Cells were transfected with a siRNA against GR. The Western blot shows that GR protein was significantly decreased in siGR-transfected cells in comparison to controls.

B. GR activity was decreased in cells treated with siGR compared to controls or cells treated with siNEG.

C. MIA PaCa-2 cells were transfected with a siRNA against GR and treated with ascorbate ( $2 \mathrm{mM}$ for $1 \mathrm{~h}$ ) and clonogenic survival was determined. Treatment with siGR had little effect on clonogenic survival while cells treated with ascorbate showed a significant decrease in clonogenic survival, $* P<0.001 \mathrm{Vs}$. control, means $\pm \mathrm{SEM}, n=3$. Additionally, treatment with a combination of siGR and ascorbate enhanced ascorbate-induced cytotoxicity $(* * P<0.001$ Vs. ascorbate, means \pm SEM, $n=3)$. 
A.

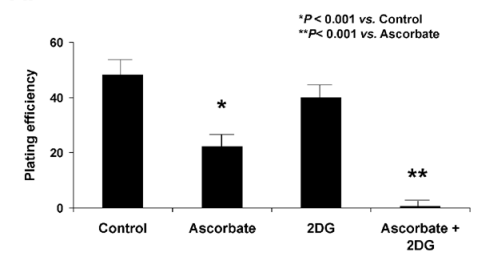

C.

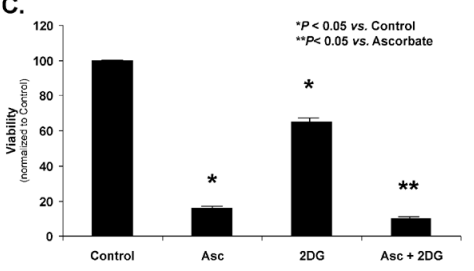

E.

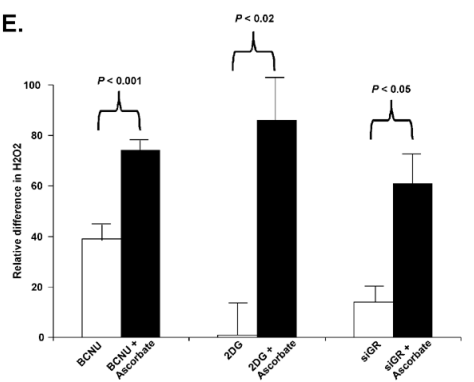

B.

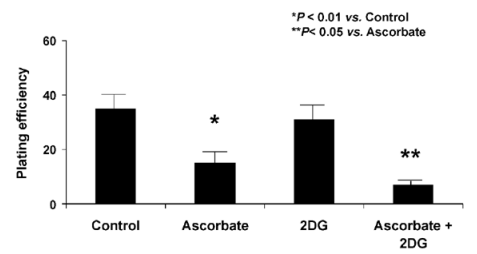

D.

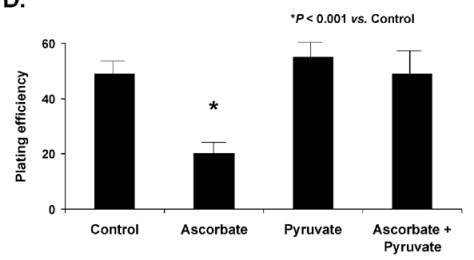

$\mathbf{F}$

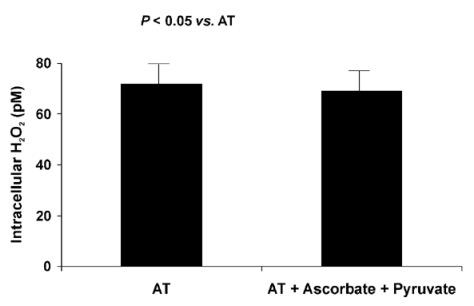

Figure 5. Inhibitors of $\mathrm{H}_{2} \mathrm{O}_{2}$ removal enhance ascorbate-induced cytotoxicity and increase intracellular concentrations of $\mathrm{H}_{2} \mathrm{O}_{2}$

A. Mia PaCa- 2 cells were treated with $2 \mathrm{DG}(25 \mathrm{mM})$ and ascorbate $(2 \mathrm{mM})$ for $1 \mathrm{~h}$ and clonogenic survival was determined. Ascorbate treatment caused a decrease in clonogenic survival ( $* P<0.001 v s$. control, means \pm SEM, $n=12)$. Treatment with $2 \mathrm{DG}(25 \mathrm{mM}) \mathrm{did}$ not affect clonogenic survival but the combination of 2DG $(25 \mathrm{mM})$ and ascorbate showed a significant enhancement in ascorbate-induced cytotoxicity, $* * P<0.001 \mathrm{Vs}$. ascorbate, means \pm SEM, $n=6$.

B. AsPC-1 cells were treated with $2 \mathrm{DG}(25 \mathrm{mM})$ and ascorbate $(2 \mathrm{mM})$ for $1 \mathrm{~h}$ and clonogenic survival was determined. Ascorbate treatment caused a decrease in clonogenic survival ( $* P<0.01$ vs. control, means \pm SEM, $n=3)$. Treatment with 2DG $(25 \mathrm{mM})$ did not affect clonogenic survival but the combination of 2DG $(25 \mathrm{mM})$ and ascorbate showed a significant enhancement in ascorbate-induced cytotoxicity, $* * P<0.05 \mathrm{Vs}$. ascorbate, means \pm SEM, $n=3$.

C. MTT assay demonstrated significant decreases in cell viability in MIA PaCa-2 and AsPC-1 cells treated with the combination of ascorbate and 2DG. Ascorbate significantly decreased viability while the combination of ascorbate and 2DG further decreased viability ( $n=4, * P<0.05$ Vs. control, $* * P<0.05$ Vs. ascorbate). Similar trends were seen with AsPC-1 cells treated with ascorbate $\pm 2 \mathrm{DG}$ (data not shown).

D. Cells were treated with pyruvate $(5 \mathrm{mM})$ and ascorbate $(2 \mathrm{mM})$ for $1 \mathrm{~h}$ and clonogenic survival determined. Cells treated with ascorbate showed a significant decrease in clonogenic survival ( $* P<0.001 v s$. control, means \pm SEM, $n=3)$. Pyruvate $(5 \mathrm{mM})$, a scavenger of $\mathrm{H}_{2} \mathrm{O}_{2}$ was able to reverse the toxicity of ascorbate. Pyruvate alone $(5 \mathrm{mM})$ did not affect clonogenic survival.

E. MIA PaCa-2 cells were treated with BCNU $(25 \mu \mathrm{M}), 2 \mathrm{DG}(25 \mathrm{mM})$, or siGR and ascorbate $(20 \mathrm{mM})$ for $1 \mathrm{~h}$, and the concentration of intracellular $\mathrm{H}_{2} \mathrm{O}_{2}$ was measured. All cells treated with a combination of their respective inhibitor of hydroperoxide metabolism 
and ascorbate showed significant increases in intracellular $\mathrm{H}_{2} \mathrm{O}_{2}$ concentrations when compared to the inhibitors of hydroperoxide removal alone (Means \pm SEM, $n=3$ ). F. MIA PaCa- 2 cells were treated with pyruvate $(5 \mathrm{mM})$ and ascorbate $(20 \mathrm{mM})$ for $1 \mathrm{~h}$, and the concentration of intracellular $\mathrm{H}_{2} \mathrm{O}_{2}$ was measured. Cells treated with a combination of pyruvate and ascorbate showed no change in intracellular $\mathrm{H}_{2} \mathrm{O}_{2}$ concentration when compared to control cells (Means \pm SEM, $n=3$ ). 


\section{Table 1}

OCR of pharmacological ascorbate in DMEM growth media*

\begin{tabular}{cc}
\hline Ascorbate $(\mathbf{m M})$ & OCR $\left(\mathbf{n M ~ s}^{-\mathbf{1}}\right)$ \\
\hline 0 & $<1^{\dagger}$ \\
2 & $61 \pm 12$ \\
5 & $114 \pm 16$ \\
10 & $224 \pm 1$ \\
20 & $334 \pm 45$ \\
\hline
\end{tabular}

This is the rate of oxygen uptake by the media upon addition of ascorbate. No cells were present, $n=3$.

${ }^{\dagger}$ Sometimes minor electrode drift contributed to an apparent low OCR. This was always much less than with ascorbate. 